\title{
Arbuscular mycorrhizal fungal communities in sub-Saharan Savannas of Benin, West Africa, as affected by agricultural land use intensity and ecological zone
}

\author{
Atti Tchabi • Danny Coyne $\cdot$ Fabien Hountondji • \\ Louis Lawouin • Andres Wiemken · Fritz Oehl
}

Received: 7 September 2007 / Accepted: 7 March 2008 / Published online: 2 April 2008

(C) Springer-Verlag 2008

\begin{abstract}
The rapid decline of soil fertility of cultivated lands in the sub-Saharan savannas of West Africa is considered to be the main cause of the increasingly severe constraints of food production. The soils in this tropical area are highly fragile, and crop yields are limited by characteristically low levels of available phosphorus. Under such preconditions, the multiple benefits of the arbuscular mycorrhizal (AM) symbiosis are likely to play a pivotal role for maintaining natural soil fertility by enhancing plant nutrient use efficiency, plant health, and stabilization of a favorable soil structure. Thus, it is important to explore the impact of the commonly applied farming practices on the native AM fungal community. In the present study, we determined the AM fungal species composition in three ecological zones differing by an increasingly prolonged dry season from South to North, from the Southern Guinea Savanna (SG), to the Northern Guinea Savanna (NG), to
\end{abstract}

A. Tchabi $\cdot$ A. Wiemken $\cdot$ F. Oehl $(\triangle)$

Plant Science Center Zurich-Basel, Institute of Botany, University of Basel,

Hebelstrasse 1,

CH-4056 Basel, Switzerland

e-mail: fritz.oehl@unibas.ch

A. Tchabi $\cdot$ F. Hountondji $\cdot$ L. Lawouin

International Institute of Tropical Agriculture (IITA),

08 BP 0932 Cotonou, Benin

D. Coyne

International Institute of Tropical Agriculture (IITA),

Oyo Road,

Ibadan, Nigeria

D. Coyne

Lambourn Ltd,

Carolyn House, 26 Dingwall Road,

Croydon CR9 3EE, UK the Sudan Savanna (SU). In each zone, four "natural" and four "cultivated" sites were selected. "Natural" sites were three natural forest savannas (at least 25-30 years old) and a long-term fallow (6-7 years old). "Cultivated" sites comprised a field with yam (Dioscorea spp.) established during the first year after forest clearance, a field under mixed cropping with maize (Zea mays) and peanut (Arachis hypogaea), a field under peanut, and a field under cotton (Gossypium hirsutum) which was the most intensively managed crop. Soil samples were collected towards the end of the wet season in each zone. AM fungal spores were extracted and morphologically identified. Soil subsamples were used to inoculate AM fungal trap cultures using Stylosanthes guianensis and Brachiaria humidicola as host plants to monitor AM root colonization and spore formation over 10 and 24 months, respectively. A total of 60 AM fungal species were detected, with only seven species sporulating in the trap cultures. Spore density and species richness were generally higher in the natural savannas and under yam than at the other cultivated sites and lowest under the intensively managed cotton. In the fallows, species richness was intermediate, indicating that the high richness of the natural savannas was not restored. Surprisingly, higher species richness was observed in the SU than in the SG and NG, mainly due to a high proportion of species in the Gigasporaceae, Acaulosporaceae, and Glomeraceae. We conclude that the West African savannas contain a high natural AM fungal species richness, but that this natural richness is significantly affected by the common agricultural land use practices and appears not to be quickly restored by fallow.

Keywords Agroecology Arbuscular mycorrhiza .

Biodiversity · Dioscorea spp. Ecological zones .

Farming practices $\cdot$ Forest $\cdot$ Yam $\cdot$ Arid lands 


\section{Introduction}

Arbuscular mycorrhizal fungi (AMF) occur in most vegetation types and constitute an important component of the tropical soil microflora (Sieverding 1991; Smith and Read 1997; Cardoso and Kuyper 2006). Knowledge and understanding of the community structure and dynamics within AMF communities, however, is a necessary prerequisite to eventually identify the specific beneficial effects of individual AMF, especially in tropical low-input agro-ecosystems in which sustainable management of the generally low soil nutrient resources must consider the benefits of native microorganisms (Cardoso and Kuyper 2006; Lovera and Cuenca 2007). During the infancy of AMF systematics (Gerdemann and Trappe 1974; Morton and Benny 1990), species diversity studies were few and generally limited (e.g., Gerdemann and Trappe 1974; Nicolson and Schenck 1979; Schenck et al. 1984) without consideration of climatic, vegetation, or land use changes. Often, the main purpose of these studies was the description of newly discovered species based on spore morphology. Further progress in this field (e.g., Schenck and Pérez 1990) and particularly the rapid development of molecular tools for identification (e.g., Redecker 2000), have steadily increased the number of AMF distribution and diversity studies and their quality in the recent past (e.g., Jansa et al. 2002; Wubet et al. 2003; Castillo et al. 2006; Gai et al. 2006; Bashan et al. 2007; Wu et al. 2007). Such studies have enabled progressive understanding of the connection between AMF communities and various parameters along broad gradients, such as land use intensity (Jansa et al. 2002; Oehl et al. 2003, 2004), soil type (Lekberg et al. 2007), soil depth (Oehl et al. 2005), host specificities (Bever et al. 2001; Eom et al. 2004), plant nutrient content (Egerton-Warburton and Allen 2000; Landis et al. 2004), spatial, temporal (Lovelock et al. 2003; Lovelock and Ewel 2005), and latitude (Koske et al. 1997) gradients. AMF identification and diversity studies from African ecosystems, however, are to date, relatively limited (e.g., Sieverding 1988; Stutz and Morton 1996; Wubet et al. 2004, 2006; Uhlmann et al. 2006; Lekberg et al. 2007; Mathimaran et al. 2007), with a particular scarcity from tropical West Africa (Old et al. 1973; Ingleby et al. 1994; Dalpé et al. 2000; Friberg 2001; Duponnois et al. 2001; Sanginga et al. 1999). AMF distribution and diversity in tropical ecosystems elsewhere appears to be receiving increased attention (e.g., Sieverding 1989; Maia and Trufem 1990; Picone 2000; Husband et al. 2002a, b; Lovelock et al. 2003; Lovelock and Ewel 2005).

In West Africa, particularly Benin, the impact of farming practices on composition and diversity of AMF remains largely unknown. The slash and burn technique of land clearance tends to prevail in many areas, leaving the land to fallow after a number of cultivation cycles. The Sudan and Guinea savannas of West Africa occur in a zone commonly referred to as the "yam belt" where yam (Dioscorea spp.) is of particular importance and characteristically is used as the first crop cultivated after forest clearing (IITA 2004). Depending on production levels, the same land is cultivated with other crops 1 or 2 years after yam, such as maize (Zea mays), sorghum (Sorghum spp.), peanut (Arachis hypogaea), cassava (Manihot esculenta), and later cotton (Gossypium hirsutum). The crops are generally cultivated in small-scale fields as mono-cropping or mixed cropping during the wet season, rotating the crops from one season to another. Except for cotton, which is cultivated as a cash crop, other crops are managed on low external input level and are intended to meet local demand (IITA 2006). Use of agricultural machinery - even for soil cultivation - is not common and where present is applied to grow cotton. "Ferralsol" soils are dominant in Benin and are characterized by low nutrient availability and high levels of soil degradation through physical loss and leaching of soil minerals, particularly

Table 1 Some geographic characteristics of the sub-Saharan ecological zones under study for arbuscular mycorrhizal fungi

\begin{tabular}{llll}
\hline Parameters & Sudan savanna & Northern Guinea savanna & Southern Guinea savanna \\
\hline Latitude & $9-11^{\circ} \mathrm{N}$ & $8-9^{\circ} \mathrm{N}$ & $7-8^{\circ} \mathrm{N}$ \\
Elevation (m.a.s.1.) & 550 & 400 & 200 \\
Climate & One wet season: May-October & One wet season: April-October & Two wet seasons: March-July and \\
& $\left(22-34^{\circ} \mathrm{C}\right)$ & $\left(22-34^{\circ} \mathrm{C}\right)$ & September-November $\left(20-28^{\circ} \mathrm{C}\right)$ \\
& One dry season: Oct-May $\left(15-45^{\circ} \mathrm{C}\right)$ & One dry season: Nov-Mar & Two dry seasons: Dec-Mar and \\
& & $\left(20-40^{\circ} \mathrm{C}\right)$ & Aug-Sep $\left(24-30^{\circ} \mathrm{C}\right)$ \\
Rainfall $(\mathrm{mm})$ & $600-700$ & $1,000-1,200$ & $1,200-1,400$ \\
Vegetation & Zyziphus mauritania, Combretum spp., & Isoberlinia doka, Afzelia africana, & Combretaceae, Mimosaceae, Fabaceae, \\
& Balamiten spp., Acacia spp., & Khaya senegalensis, Danielia & Poaceae \\
& Butyrospermum spp., Parkia & oliveri, Anogeissus spp., & \\
& biglobosa, Andropogon gayanus, & Pterocarpus spp., Andropogon spp. & \\
& Imperata cylindrica & & \\
\hline
\end{tabular}

Sources: Adjakidje (1984), Adjanohoun (1989). 
available phosphorus, due to heavy rains, resulting in rapid yield decline (Defoer and Scoones 2001; IITA 2006). Soil infertility and subsequent yield decline is also partly related to the decreasing prevalence and loss of diversity of soil microflora and microfauna, such as beneficial AMF, after forest clearance (Johnson et al. 1992).

The present study investigated the impact of land use intensity on AMF communities in three ecological zones of Benin: the Sudan Savanna (SU) and the Northern and
Southern Guinea Savannas (NG and SG, respectively). Based on similar studies elsewhere (e.g., Sieverding 1989; Jansa et al. 2002; Oehl et al. 2003), we hypothesized that agricultural cultivation practices such as crop rotation and cultivation of specific crops would lead to an erosion of AMF species diversity in West African soils. We further expected that AMF species composition changes with increasing dry season length from south to north succession of savanna types ( $\mathrm{SG}$ through $\mathrm{NG}$ to $\mathrm{SU}$ ). To achieve an

Table 2 Historical characteristics (cultural precedence, fallow duration, crop rotation, fertilizer, and pesticide use) of sites in Benin sampled for arbuscular mycorrhizal fungi

\begin{tabular}{|c|c|c|c|c|c|}
\hline $\begin{array}{l}\text { Standing crops/ } \\
\text { vegetation } \\
\text { at sampling date }\end{array}$ & $\begin{array}{l}\text { Previous crops/ } \\
\text { vegetation }\end{array}$ & $\begin{array}{l}\text { Estimated age of } \\
\text { the forest or } \\
\text { fallow (year) }\end{array}$ & $\begin{array}{l}\text { Years of continuous } \\
\text { cultivation after } \\
\text { forest clearance }\end{array}$ & Historic of fertilizer use & $\begin{array}{l}\text { Historic of pesticide } \\
\text { use }\end{array}$ \\
\hline \multicolumn{6}{|l|}{ Sudan savanna (SU) } \\
\hline Natural Forest1 & - & $25-30$ & - & - & - \\
\hline Natural Forest2 & - & $25-30$ & - & - & - \\
\hline Natural Forest3 & - & $25-30$ & - & - & - \\
\hline Yam & Natural forest & - & 1 & - & - \\
\hline $\begin{array}{l}\text { Mixed crops } \\
\quad \text { (maize-peanut) }\end{array}$ & Yam & - & 2 & - & - \\
\hline Peanut & Peanut and cassava & - & 3 & - & - \\
\hline Cotton & Maize + peanut & - & 4 & $\begin{array}{l}\text { Mineral fertilizer } \\
\text { (N:P:K:S:B=14: } \\
\text { 23:14:5:1; } \\
\left.150 \mathrm{~kg} \mathrm{ha}^{-1}\right) \\
\text { Urea }\left(50 \mathrm{~kg} \mathrm{ha}^{-1}\right)\end{array}$ & $\begin{array}{l}\text { Conquest Plus 388EC } \\
\text { (Cypermetrine, } \\
\text { Acetometride and } \\
\text { Triasophos) }\end{array}$ \\
\hline Fallow & - & $6-7$ & - & - & - \\
\hline \multicolumn{6}{|c|}{ Northern Guinea savanna (NG) } \\
\hline Natural Forest1 & - & $20-25$ & - & - & - \\
\hline Natural Forest2 & - & $25-30$ & - & - & - \\
\hline Natural Forest3 & - & $20-25$ & - & - & - \\
\hline Yam & Natural forest & - & 1 & - & - \\
\hline $\begin{array}{l}\text { Mixed crops } \\
\quad \text { (maize-peanut) }\end{array}$ & Yam & - & 2 & - & - \\
\hline Peanut & Cassava & - & 3 & - & - \\
\hline Cotton & Maize + peanut & - & 4 & $\begin{array}{l}\text { Mineral fertilizer } \\
\text { (N:P:K:S:B=14:23: } \\
\left.\text { 14:5:1; } 150 \mathrm{~kg} \mathrm{ha}^{-1}\right) \text {; } \\
\text { Urea }\left(50 \mathrm{~kg} \mathrm{ha}^{-1}\right)\end{array}$ & $\begin{array}{l}\text { Conquest Plus 388EC } \\
\text { (Cypermetrine, } \\
\text { Acetometride and } \\
\text { Triasophos) }\end{array}$ \\
\hline Fallow & - & 7 & - & - & - \\
\hline \multicolumn{6}{|c|}{ Southern Guinea savanna (SG) } \\
\hline Natural Forest1 & - & $25-30$ & - & - & - \\
\hline Natural Forest2 & - & $25-30$ & - & - & - \\
\hline Natural Forest3 & - & $20-25$ & - & - & - \\
\hline Yam & Natural forest & - & 1 & - & - \\
\hline $\begin{array}{l}\text { Mixed crops } \\
\quad \text { (maize-peanut) }\end{array}$ & Yam & - & 2 & - & - \\
\hline Peanut & Maize + peanut & - & 3 & - & - \\
\hline Cotton & Maize + cassava & - & 4 & $\begin{array}{l}\text { Mineral fertilizer } \\
\text { (N:P:K:S:B=14:23: } \\
\left.\text { 14:5:1); } 150 \mathrm{~kg} \mathrm{ha}^{-1}\right) \text {; } \\
\text { Urea }\left(50 \mathrm{~kg} \mathrm{ha}^{-1}\right)\end{array}$ & $\begin{array}{l}\text { Conquest Plus 388EC } \\
\text { (Cypermetrine, } \\
\text { Acetometride and } \\
\text { Triasophos) }\end{array}$ \\
\hline Fallow & - & $5-6$ & - & - & - \\
\hline
\end{tabular}


understanding on AMF dynamics in different ecological zones, AMF spore density (=spore abundance) and species richness (=species numbers) were compared at the various agricultural sites using a gradient of land use intensity, from undisturbed natural forest savanna sites through yam fields and various low-input crops to relatively intensive cotton production, in the three ecological zones.

\section{Materials and methods}

\section{Study area}

This study was undertaken in three ecological zones of Benin: in the SU the NG and SG (Table 1). The climate changes from $\mathrm{SG}$ through $\mathrm{NG}$ to $\mathrm{SU}$, reflected by a decreasing annual rainfall and increasing length of dry season (Table 1). Moreover, the temperature differences between day and night are increasingly more pronounced with distance from south to north, especially during the dry season (Table 1). Remarkably, the SG has two wet seasons and two dry seasons per annum, while NG and SU have a single wet and dry season each per annum. The natural vegetation in the natural savannas consists of trees, shrubs, and grasses, with trees and shrubs becoming increasingly less prominent from south to north (see, e.g., Adjakidje 1984; Adjanohoun 1989; Table 1). The soils are dominantly ferruginous Ferralsols (FAO 2006: http://www.fao.org/AG/ aGL/agll/landuse/docs/benin.doc).

Study sites and soil sampling

In each ecological zone, soils were sampled at eight sites (Table 2): three in natural forest savannas where soils and plant vegetation had been undisturbed for 25-30 years before sampling; one under long-term fallow of 6-7 years; one cultivated with yam in the first season after forest clearance; two cultivated with peanut, either alone or in mixed cropping with maize; one cultivated with cotton under relatively intensive high-input conditions. The geographical position and selected chemical soil parameters were measured at each site (Table 3).

Table 3 Geographical position of study sites, and selected chemical soil parameters

\begin{tabular}{|c|c|c|c|c|c|}
\hline Sampling sites & Geographical position & $\mathrm{pH}\left(\mathrm{H}_{2} \mathrm{O}\right)$ & $\begin{array}{l}\text { Organic } \\
\mathrm{C}\left(\mathrm{g} \mathrm{kg}^{-1}\right)\end{array}$ & $\begin{array}{l}\text { Available } \mathrm{P} \text { (sodium } \\
\text { acetate; } \mathrm{mg} \mathrm{kg}^{-1} \text { ) }\end{array}$ & $\begin{array}{l}\text { Available P (citrate; } \\
\mathrm{mg} \mathrm{kg}^{-1} \text { ) }\end{array}$ \\
\hline \multicolumn{6}{|c|}{ Ecological zone 1: Sudan savanna (SU) } \\
\hline Natural Forest 1 & $10^{\circ} 56.420 \mathrm{~N} ; 001^{\circ} 32.003 \mathrm{E}$ & 6.1 & 13.9 & 47.6 & 69.9 \\
\hline Natural Forest 2 & $10^{\circ} 17.060 \mathrm{~N} ; 001^{\circ} 19.506 \mathrm{E}$ & 6.3 & 10.4 & 11.8 & 17.5 \\
\hline Natural Forest 3 & $10^{\circ} 07.868 \mathrm{~N} ; 001^{\circ} 56.315 \mathrm{E}$ & 6.5 & 23.8 & 3.9 & 8.7 \\
\hline Yam & $10^{\circ} 07.868 \mathrm{~N} ; 001^{\circ} 51.104 \mathrm{E}$ & 5.9 & 11.6 & 3.9 & 8.7 \\
\hline Mixed cropping & $10^{\circ} 18.802 \mathrm{~N} ; 001^{\circ} 35.104 \mathrm{E}$ & 6.2 & 6.4 & 7.4 & 13.1 \\
\hline Peanut & $10^{\circ} 19.885 \mathrm{~N} ; 002^{\circ} 00.326 \mathrm{E}$ & 6.2 & 12.8 & 6.5 & 13.1 \\
\hline Cotton & $09^{\circ} 58.916 \mathrm{~N} ; 002^{\circ} 47.936 \mathrm{E}$ & 5.9 & 13.9 & 47.6 & 69.8 \\
\hline Fallow & $10^{\circ} 18.802 \mathrm{~N} ; 001^{\circ} 35.104 \mathrm{E}$ & 5.9 & 6.4 & 3.9 & 4.4 \\
\hline \multicolumn{6}{|c|}{ Ecological zone 2: Northern Guinea savanna (NG) } \\
\hline Natural Forest 1 & $08^{\circ} 43.452 \mathrm{~N} ; 002^{\circ} 40.047 \mathrm{E}$ & 6.6 & 9.3 & 8.7 & 8.7 \\
\hline Natural Forest 2 & $09^{\circ} 10.545 \mathrm{~N} ; 002^{\circ} 12.321 \mathrm{E}$ & 6.5 & 28.4 & 13.1 & 21.8 \\
\hline Natural Forest 3 & $09^{\circ} 03.112 \mathrm{~N} ; 002^{\circ} 04.197 \mathrm{E}$ & 6.7 & 36.0 & 46.3 & 65.5 \\
\hline Yam & $08^{\circ} 54.966 \mathrm{~N} ; 002^{\circ} 33.370 \mathrm{E}$ & 5.8 & 11.0 & 7.0 & 8.7 \\
\hline Mixed cropping & $09^{\circ} 57.436 \mathrm{~N} ; 001^{\circ} 51.797 \mathrm{E}$ & 6.2 & 4.1 & 5.2 & 8.7 \\
\hline Peanut & $08^{\circ} 58.619 \mathrm{~N} ; 002^{\circ} 28.714 \mathrm{E}$ & 6.2 & 13.9 & 9.2 & 13.1 \\
\hline Cotton & $09^{\circ} 21.962 \mathrm{~N} ; 001^{\circ} 34.121 \mathrm{E}$ & 5.8 & 11.0 & 25.8 & 52.4 \\
\hline Fallow & $08^{\circ} 54.966 \mathrm{~N} ; 002^{\circ} 33.370 \mathrm{E}$ & 6.5 & 13.3 & 13.1 & 21.8 \\
\hline \multicolumn{6}{|c|}{ Ecological zone 3: Southern Guinea savanna (SG) } \\
\hline Natural Forest 1 & $07^{\circ} 45.739 \mathrm{~N} ; 002^{\circ} 27.519 \mathrm{E}$ & 6.7 & 9.9 & 14.8 & 34.9 \\
\hline Natural Forest 2 & $07^{\circ} 57.217 \mathrm{~N} ; 002^{\circ} 26.935 \mathrm{E}$ & 7.2 & 13.9 & 8.7 & 13.1 \\
\hline Natural Forest 3 & $07^{\circ} 35.829 \mathrm{~N} ; 002^{\circ} 18.942 \mathrm{E}$ & 6.4 & 13.9 & 28.4 & 43.6 \\
\hline Yam & $07^{\circ} 55.111 \mathrm{~N} ; 002^{\circ} 10.507 \mathrm{E}$ & 7.4 & 13.3 & 5.7 & 8.7 \\
\hline Mixed cropping & $07^{\circ} 25.639 \mathrm{~N} ; 001^{\circ} 51.323 \mathrm{E}$ & 6.2 & 9.9 & 14.8 & 34.9 \\
\hline Peanut & $07^{\circ} 51.537 \mathrm{~N} ; 002^{\circ} 17.246 \mathrm{E}$ & 6.6 & 7.5 & 13.1 & 17.5 \\
\hline Cotton & $07^{\circ} 23.024 \mathrm{~N} ; 001^{\circ} 52.495 \mathrm{E}$ & 6.2 & 16.2 & 43.7 & 61.1 \\
\hline Fallow & $07^{\circ} 49.275 \mathrm{~N} ; 002^{\circ} 15155 \mathrm{E}$ & 6.5 & 9.9 & 10.5 & 17.5 \\
\hline
\end{tabular}

$E$ east of Greenwich, $N$ north of the Equator 
Sites were sampled towards the end of the wet season, in October 2004, when vegetation cover remained green and yam was approximately 5-6 months old. At each sampling site, four replicate quadrant plots $\left(100 \mathrm{~m}^{2}\right)$ were selected, and six soil cores randomly removed to a depth of $20 \mathrm{~cm}$ using $6-\mathrm{cm} \varnothing$ corers. The six soil-core samples per plot were combined as one composite sample constituting one replicate per site. Samples were stored in plastic bags and transported within $24-72 \mathrm{~h}$ to the International Institute of Tropical Agriculture station in Abomey-Calavi (IITA-Benin), air-dried on an open bench in the greenhouse for $72 \mathrm{~h}$, and then held at $4^{\circ} \mathrm{C}$ in a fridge for 2 weeks before transferal to the Botanical Institute of Basel (Switzerland).

\section{Soil analyses}

Each replicate air-dried soil sample from each quadrant plot was divided into three subsets: one for the determination of chemical soil parameters ( $\mathrm{pH}$, organic carbon, and available phosphorus) in the "Laboratory Dr. Balzer", Wetter-Amönau, Germany according to standard methods (Oehl et al. 2003); the second for direct isolation and identification of AMF spores (see below); the third for use as inoculum for AMF propagation and spore production in "trap cultures" and subsequent $\mathrm{AMF}$ identification.

\section{Trap cultures}

Four trap culture pots (pots, $20 \times 20 \times 30 \mathrm{~cm}$ ) were created for each site, one each per field plot replicate according to Oehl et al. (2003). For each pot, $4 \mathrm{~kg}$ of substrate was used, comprised of a sterilized 3:1 (wt/wt) mixture of Terragreen ${ }^{\circledR}$ (a calcined granular attapulgite clay mineral, American aluminum oxide, oil dry US special, type III R, $>0.125 \mathrm{~mm}$; Lobbe Umwelttechnik, Iserlohn, Germany) and quartz sand (Alsace quartz sand, $5 \%$ of free silica, Smurfit Company, France), respectively. The chemical composition of the substrate was $0.3 \%$ organic matter, 10 and $1,480 \mathrm{mg} \mathrm{kg}^{-1}$ easily and heavily available phosphorus ( $\mathrm{P}$ extracted with sodium acetate and citrate, respectively), and $191 \mathrm{mg} \mathrm{kg}^{-1}$ potassium ( $\mathrm{K}$ extracted with sodium acetate), and $\mathrm{pH}$ 5.8. A 180-g sample, divided equally into three sub-portions of soil inoculum, was placed in each trap culture pot as three lines on the surface of $3 \mathrm{~kg}$ substrate, which was then covered with the remaining $1 \mathrm{~kg}$ of trap culture substrate. Five 1-week-old Stylosanthes guianensis plants and four 1-week-old Brachiaria humidicola plants were alternatively and equidistantly planted per pot along the three lines of the inoculum. A total of 100 pots were set up including four non-mycorrhizal control pots. Each control pot received $180 \mathrm{~g}$ sterilized soil and a non-mycorrhizal suspension of soil bacteria ( $1 \mathrm{ml}$ per plantlet) obtained through fine filtration (LS 141/2; Schleicher and Schuell, Feldbach, Switzerland) of a soil suspension (final volume of 11 bacterial soil suspension from $0.5 \mathrm{~kg}$ air-dried soil). The

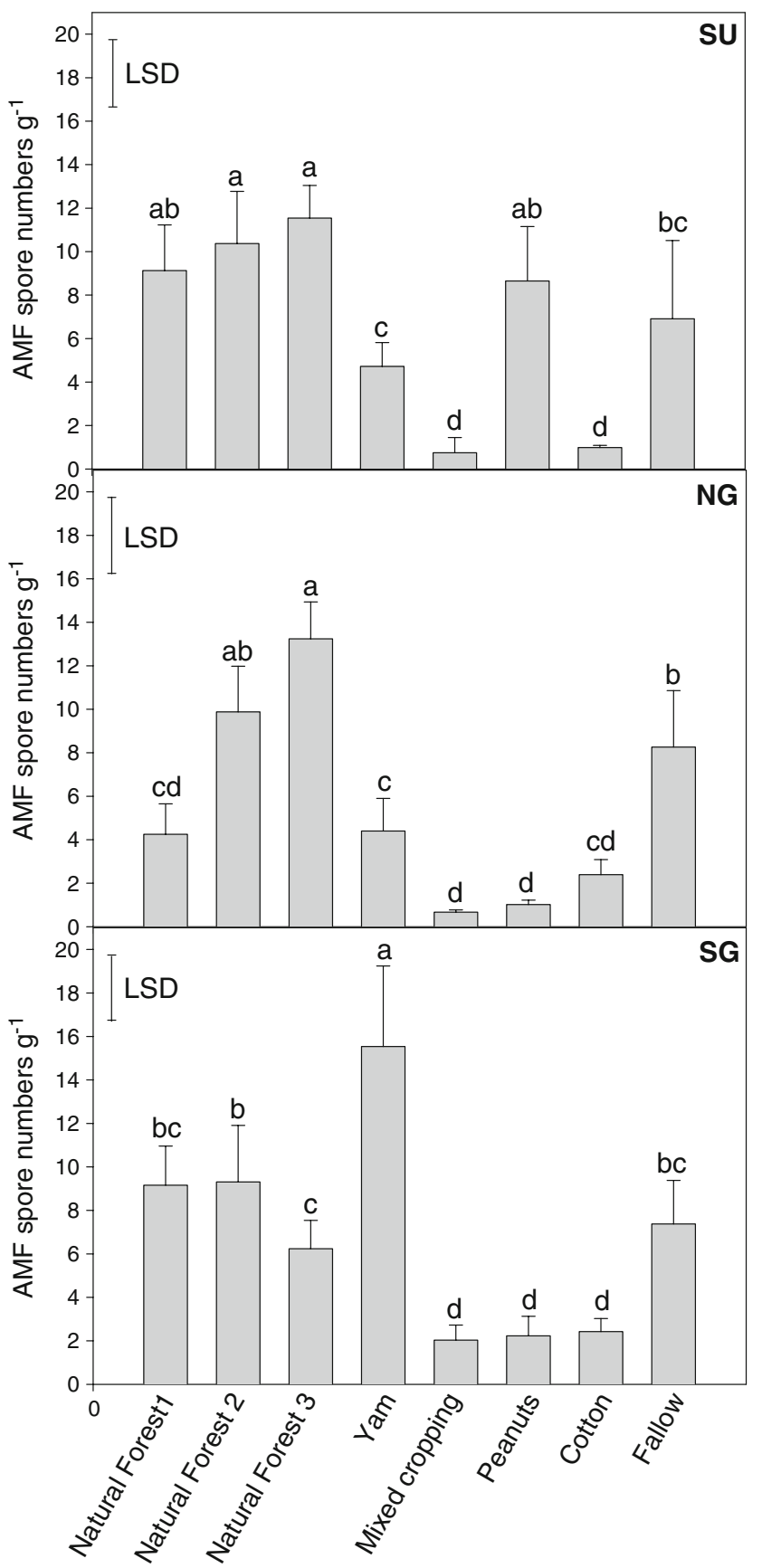

Fig. 1 AM fungal spore density (in spore numbers per gram of soil) at field sites in three agro-ecological zones: Sudan savanna $(S U)$, Northern Guinea savanna $(N G)$, and Southern Guinea savanna $(S G)$. Data are reported as averages and standard deviations for four replicate plots per field site. Non-significant differences between sites are shown by identical letters, determined using Fisher's least significant difference $(L S D)$ at the $5 \%$ level following one-way ANOVA 
Table 4 Arbuscular mycorrhizal (AM) fungal genera and species richness found at 24 sites in three ecological zones of Benin

\begin{tabular}{|c|c|c|c|c|}
\hline & SU & NG & SG & $\begin{array}{l}\text { Sum of SU, } \\
\text { NG, SG }\end{array}$ \\
\hline \multicolumn{5}{|l|}{ Glomeraceae } \\
\hline Glomus & 23 & 18 & 19 & 30 \\
\hline \multicolumn{5}{|l|}{ Acaulosporaceae } \\
\hline Acaulospora & 10 & 10 & 8 & 12 \\
\hline Kuklospora & 1 & 2 & 1 & 2 \\
\hline \multicolumn{5}{|l|}{ Gigasporaceae } \\
\hline Gigaspora & 2 & 1 & 0 & 2 \\
\hline Scutellospora & 8 & 7 & 5 & 10 \\
\hline \multicolumn{5}{|l|}{ Entrophosporaceae } \\
\hline Entrophospora & 1 & 0 & 1 & 1 \\
\hline \multicolumn{5}{|l|}{ Ambisporaceae } \\
\hline Ambispora & 1 & 1 & 1 & 1 \\
\hline \multicolumn{5}{|l|}{ Paraglomeraceae } \\
\hline Paraglomus & 1 & 0 & 0 & 1 \\
\hline Total species richness & 47 & 39 & 35 & 59 \\
\hline
\end{tabular}

$S U$ Sudan savanna, $N G$ northern Guinea savanna, $S G$ Southern Guinea savanna

trap cultures were maintained in a greenhouse in Basel for 24 months under day/night regimes of 12-h:12-h photoperiod and $25: 21^{\circ} \mathrm{C}$ temperature, with a mean relative humidity of $65 \pm 5 \%$. Trap cultures were irrigated using automated watering systems (Tropf-Blumat; Weninger GmbH, Telfs, Austria; Oehl et al. 2003).

\section{Sampling of trap cultures}

At 4, 6, 8 10, and 24 months after planting, two soil core samples (volume $15 \mathrm{~cm}^{3}$ per core) were removed from each pot for spore isolation and identification and to monitor mycorrhizal root colonization.

\section{Isolation and morphological identification of AMF}

AMF spores were isolated from $25 \mathrm{~g}$ air-dried field soil samples or from $30 \mathrm{~cm}^{3}$ trap culture substrate that were suspended in water. Spores were extracted by wet sieving through nested sieves $(1,000,125,80$, and $32 \mu \mathrm{m})$ followed by density gradient centrifugation. From the $1,000-\mu \mathrm{m}$ sieves, no spores or sporocarps were obtained, and therefore, only the contents from the 125-, 80-, and 35- $\mu \mathrm{m}$ sieves were poured into $50-\mathrm{ml}$ vials and centrifuged in $70 \%$ sucrose solution gradient (Oehl et al. 2003). After centrifugation at $2,000 \mathrm{rpm}$ for $2 \mathrm{~min}$, spores, spore clusters, and sporocarps obtained from each pot were transferred into Petri dishes and counted using a dissecting microscope (Olympus SZ12) at up to $90 \times$ magnification.
For microscopic identification, healthy spores were mounted on glass slides and stained with polyvinyl-lactic acid glycerol mixed with Melzer's reagent (1:1 vol/vol; Brundrett et al. 1994). The spores were examined under a compound microscope (Zeiss; Axioplan) at up to $400 \times$

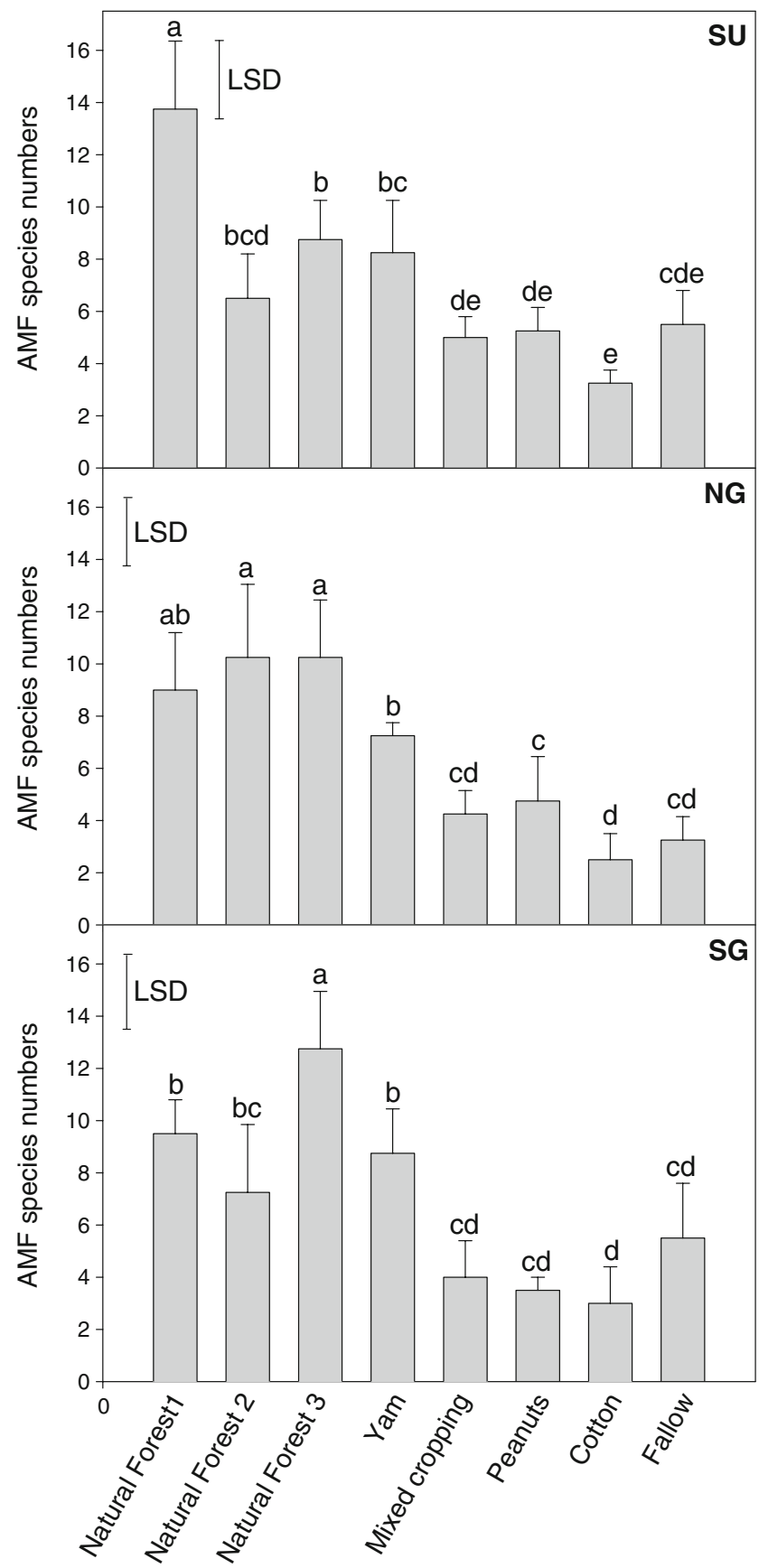

Fig. 2 AM fungal species richness at field sites in three agroecological zones: Sudan savanna $(S U)$, Northern Guinea savanna $(N G)$, and Southern Guinea savanna $(S G)$. Data are reported as averages and standard deviations for four replicate plots per field site. Non-significant differences between sites are shown by identical letters, determined using Fisher's least significant difference $(L S D)$ at the $5 \%$ level following one-way ANOVA 
magnification. Identification was based on current species descriptions and identification manuals [Schenck and Pérez 1990; International Culture Collection of Arbuscular and Vesicular-Arbuscular Endomycorrhizal Fungi, INVAM: http://invam.caf.wvu.edu; Arbuscular Mycorrhizal Fungi (Glomeromycota), Endogone and Complexipes species deposited in the Department of Plant Pathology, University of Agriculture in Szczecin, Poland: http://www.agro.ar. szczecin.pl/ jblaszkowski/].

Statistical analysis

Spore density (=spore abundance) in a field sample was expressed as the number of AMF spores per gram of soil.
Spore density and species richness were analyzed using the PROC analysis of variance (ANOVA) procedure of SAS version 9.1 packages (SAS, 2005). Significant differences between field sites were tested using Fisher's least significant difference (LSD) at $P<0.05$. Before analysis, data on spore density were $\log (x+1)$ transformed to normalize the data.

\section{Results}

Soil characteristics

Soils were slightly acid across zones (Table 3). In general, natural forest savanna sites had relatively higher
Table 5 AM fungal species richness under various land use systems: natural forest savannas, cultivated fields, and fallows of three ecological zones in Benin
$S U$ Sudan savanna, $N G$ northern Guinea savanna, $S G$ southern Guinea savanna

\begin{tabular}{|c|c|c|c|c|c|c|c|c|}
\hline $\begin{array}{l}\text { AMF family/genera } \\
\text { and ecological zones }\end{array}$ & $\begin{array}{l}\text { Natural } \\
\text { forest } 1\end{array}$ & $\begin{array}{l}\text { Natural } \\
\text { forest } 2\end{array}$ & $\begin{array}{l}\text { Natural } \\
\text { forest } 3\end{array}$ & Yam & $\begin{array}{l}\text { Mixed } \\
\text { cropping }\end{array}$ & Peanut & Cotton & Fallow \\
\hline \multicolumn{9}{|l|}{ Glomeraceae } \\
\hline \multicolumn{9}{|l|}{ Glomus } \\
\hline SU & 13 & 10 & 10 & 8 & 3 & 8 & 5 & 7 \\
\hline NG & 7 & 10 & 8 & 7 & 4 & 5 & 4 & 6 \\
\hline SG & 9 & 9 & 8 & 10 & 5 & 3 & 4 & 6 \\
\hline \multicolumn{9}{|l|}{ Acaulosporaceae } \\
\hline \multicolumn{9}{|l|}{ Acaulospora } \\
\hline SU & 4 & 6 & 2 & 7 & 2 & 4 & & 2 \\
\hline NG & 3 & 7 & 5 & 2 & 3 & 1 & 1 & \\
\hline SG & 3 & 1 & 3 & 3 & 3 & 2 & 1 & 3 \\
\hline \multicolumn{9}{|l|}{ Kuklospora } \\
\hline SU & & & & & 1 & & & \\
\hline NG & 1 & 2 & 1 & & & & & \\
\hline SG & & 1 & & & & & & \\
\hline \multicolumn{9}{|l|}{ Gigasporaceae } \\
\hline \multicolumn{9}{|l|}{ Gigaspora } \\
\hline SU & 1 & & & & 1 & 1 & & \\
\hline NG & & & 1 & & & 1 & & \\
\hline \multicolumn{9}{|l|}{ SG } \\
\hline \multicolumn{9}{|l|}{ Scutellospora } \\
\hline SU & 6 & 1 & 4 & 2 & 3 & 1 & & 1 \\
\hline NG & 4 & 1 & 3 & 2 & & 4 & & \\
\hline SG & 3 & 3 & 2 & 1 & & & & 1 \\
\hline \multicolumn{9}{|l|}{ Entrophosporaceae } \\
\hline \multicolumn{9}{|l|}{ Entrophospora } \\
\hline SU & & 1 & & 1 & & & & \\
\hline \multicolumn{9}{|l|}{ NG } \\
\hline SG & & & 1 & & & & & \\
\hline \multicolumn{9}{|l|}{ Ambisporaceae } \\
\hline \multicolumn{9}{|l|}{ Ambispora } \\
\hline SU & 1 & & & & & & & \\
\hline NG & & & 1 & & & & & \\
\hline SG & & & 1 & & & 1 & & \\
\hline \multicolumn{9}{|l|}{ Paraglomeraceae } \\
\hline \multicolumn{9}{|l|}{ Paraglomus } \\
\hline SU & 1 & & & & & & & \\
\hline NG & & & & & & & & \\
\hline SG & & & & & & & & \\
\hline
\end{tabular}




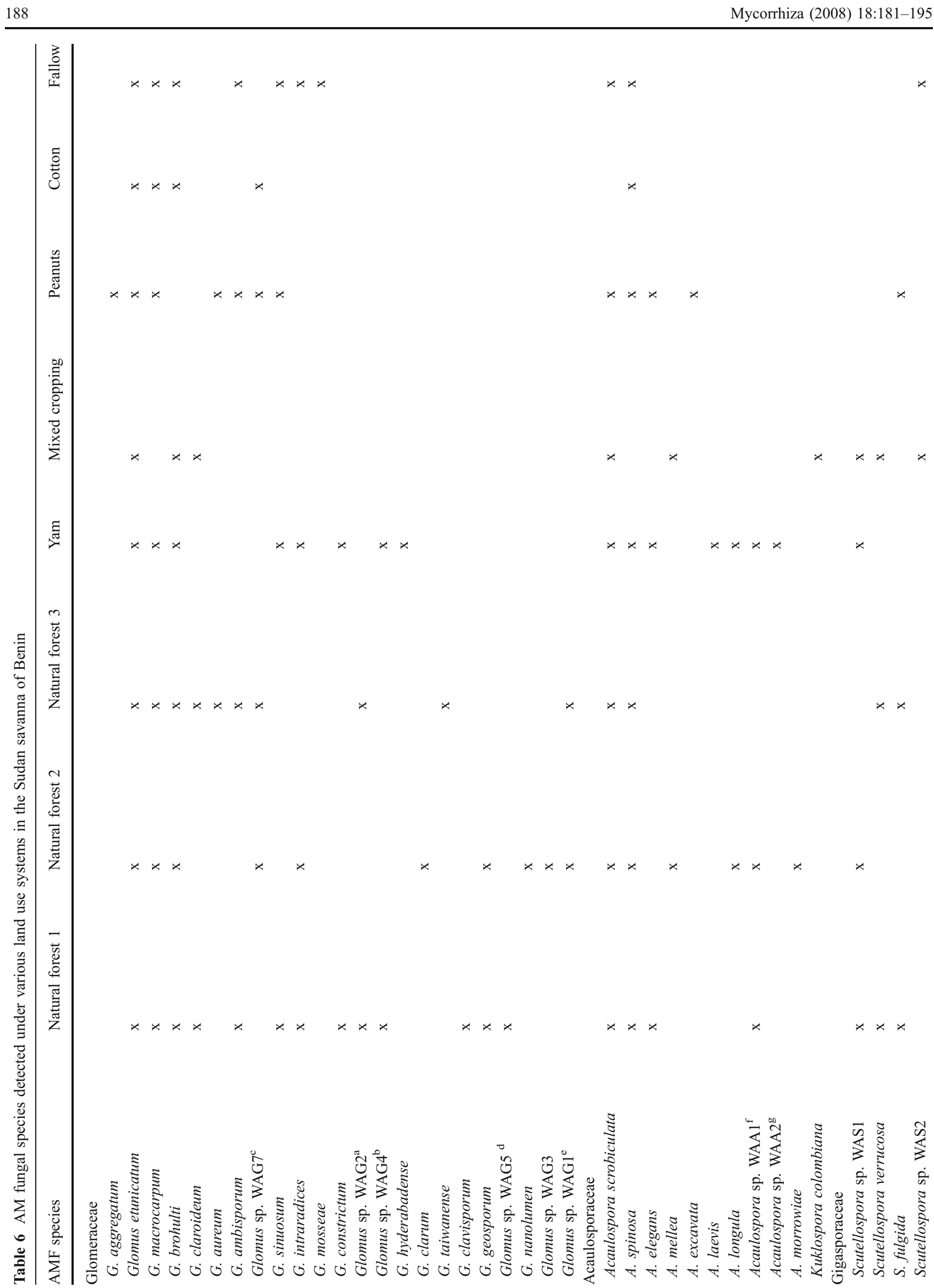

Springer 


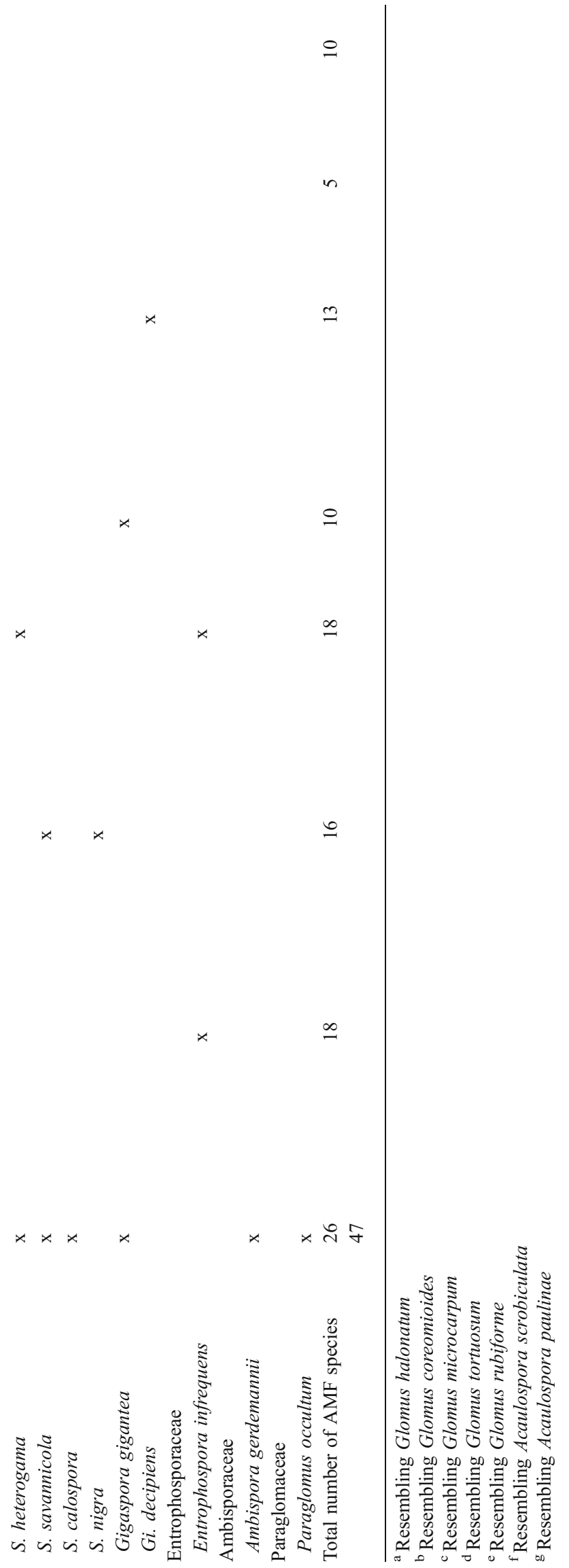

soil organic matter content and available P (phosphorus) than cultivated sites (except cotton fields). The C (carbon) and $\mathrm{P}$ soil contents also were dramatically reduced once under crop cultivation. Available P in the cotton fields, however, was similar to forest sites, probably as a result of fertilizer application. In the fallows, organic $\mathrm{C}$ and available $\mathrm{P}$ contents were similar to peanut or mixed cropping sites.

AMF spore density

AMF spore density was generally higher at the natural sites than at the cultivated sites. With a few exceptions, forest soil spore density was consistently higher compared with peanut, mixed cropping, and cotton sites (Fig. 1). Spore density was similar in cultivated sites, but yam fields in SG had notably higher spore density than at all other sites, followed by forest and fallow soils. Spore density at fallow sites was variable, but generally comparable to forest sites. The lowest spore densities were observed under mixed cropping and in cotton fields in all three ecological zones (Fig. 1).

\section{AMF species richness}

A total of 59 AMF species were detected in soils sampled from the 24 sites in the study area (Table 4). Thirty species belonged to the genus Glomus in the family Glomeraceae, 12 species to Acaulospora, and two species to Kuklospora in the Acaulosporaceae. There were ten Scutellospora and two Gigaspora species in the Gigasporaceae. One species each belonged to the families Entrophosporaceae, Archaeosporaceae, Ambisporaceae, and Paraglomeraceae. The total number of AMF species detected was higher in the SU (47 species) than in the NG and SG (39 and 35, respectively; Table 4). A relatively greater proportion of particularly Scutellospora spp. and Gigaspora spp., but also of Glomus spp. and Acaulospora spp., was apparent in the SU than in the $\mathrm{NG}$ and SG.

AMF species richness and land use

AMF species richness was generally higher $(P<0.05)$ in natural forest and yam field soils when compared to other field crop sites (Fig. 2). With one exception of yam fields in $\mathrm{SU}$, species richness was higher than in other cultivated or fallow sites (Fig. 2). However, no difference in species richness was observed between any of the cotton, mixed cropping, peanut, or fallow sites (Fig. 2).

Independent of the ecological zone, land cultivation negatively affected the species richness, particularly species of Gigasporaceae and sporocarp-forming Glomus species, 
such as Glomus clavisporum, $G$. pachycaulis, and $G$. taiwanense (Tables 5, 6, 7 and 8). The number of species of Acaulosporaceae was also reduced, while a few Glomus species (e.g., G. etunicatum, G. macrocarpum, and $G$. intraradices) and Acaulospora scrobiculata were less affected, with higher spore densities recorded under cotton production. These four species were recovered from most of the 24 sites under investigation.

Table 7 AM fungal species detected under various land use systems in the northern Guinea savanna of Benin

\begin{tabular}{|c|c|c|c|c|c|c|c|c|}
\hline AMF species & $\begin{array}{l}\text { Natural } \\
\text { forest } 1\end{array}$ & $\begin{array}{l}\text { Natural } \\
\text { forest } 2\end{array}$ & $\begin{array}{l}\text { Natural } \\
\text { forest } 3\end{array}$ & Yam & $\begin{array}{l}\text { Mixed } \\
\text { cropping }\end{array}$ & Peanuts & Cotton & Fallow \\
\hline \multicolumn{9}{|l|}{ Glomeraceae } \\
\hline Glomus etunicatum & $\mathrm{x}$ & $\mathrm{x}$ & $\mathrm{x}$ & $\mathrm{x}$ & $\mathrm{x}$ & $\mathrm{x}$ & $\mathrm{x}$ & $\mathrm{x}$ \\
\hline G. macrocarpum & $\mathrm{x}$ & $\mathrm{x}$ & $\mathrm{x}$ & & $\mathrm{x}$ & $\mathrm{x}$ & $\mathrm{x}$ & $\mathrm{x}$ \\
\hline G. brohulti & $\mathrm{x}$ & $\mathrm{x}$ & $\mathrm{x}$ & $\mathrm{x}$ & & $\mathrm{x}$ & $\mathrm{x}$ & $\mathrm{x}$ \\
\hline G. intraradices & & $\mathrm{x}$ & $\mathrm{x}$ & $\mathrm{x}$ & $\mathrm{x}$ & $\mathrm{x}$ & $\mathrm{x}$ & \\
\hline G. constrictum & $\mathrm{x}$ & $\mathrm{x}$ & $\mathrm{x}$ & & $\mathrm{x}$ & & & $\mathrm{x}$ \\
\hline G. claroideum & & & $\mathrm{x}$ & & & & & \\
\hline G. sinuosum & & & $\mathrm{x}$ & $\mathrm{x}$ & & & & \\
\hline G. microaggregatum & & & & $\mathrm{x}$ & & $\mathrm{x}$ & & $\mathrm{x}$ \\
\hline Glomus sp. WAG3 & & $\mathrm{x}$ & & & & & & $\mathrm{x}$ \\
\hline G. versiforme & & & & $\mathrm{x}$ & & & & \\
\hline Glomus sp. WAG7 ${ }^{\mathrm{a}}$ & & & & $\mathrm{x}$ & & & & \\
\hline G. clavisporum & $\mathrm{x}$ & $\mathrm{x}$ & & & & & & \\
\hline G. taiwanense & $\mathrm{x}$ & & & & & & & \\
\hline Glomus sp. WAG2 ${ }^{\mathrm{b}}$ & $\mathrm{x}$ & & & & & & & \\
\hline G. aureum & & $\mathrm{x}$ & & & & & & \\
\hline G. eburneum & & $\mathrm{x}$ & & & & & & \\
\hline G. fasciculatum & & $\mathrm{x}$ & & & & & & \\
\hline G. hoi & & & $\mathrm{x}$ & & & & & \\
\hline \multicolumn{9}{|l|}{ Acaulosporaceae } \\
\hline Acaulospora scrobiculata & $\mathrm{x}$ & $\mathrm{x}$ & $\mathrm{x}$ & $\mathrm{x}$ & $\mathrm{x}$ & & $\mathrm{x}$ & \\
\hline A. mellea & & $\mathrm{x}$ & $\mathrm{x}$ & & & $\mathrm{x}$ & & \\
\hline A. laevis & & & & & $\mathrm{x}$ & & & \\
\hline A. cavernata & & & & & $\mathrm{x}$ & & & \\
\hline Acaulospora sp. WAA1 ${ }^{\mathrm{c}}$ & $\mathrm{x}$ & $\mathrm{x}$ & $\mathrm{x}$ & $\mathrm{x}$ & & & & \\
\hline A. elegans & & & $\mathrm{x}$ & & & & & \\
\hline A. spinosa & $\mathrm{x}$ & $\mathrm{x}$ & $\mathrm{x}$ & & & & & \\
\hline A. excavata & & $\mathrm{x}$ & & & & & & \\
\hline A. longula & & $\mathrm{x}$ & & & & & & \\
\hline Acaulospora sp. WAA2 & & $\mathrm{x}$ & & & & & & \\
\hline Kuklospora kentinensis & $\mathrm{x}$ & $\mathrm{x}$ & $\mathrm{x}$ & & & & & \\
\hline K. colombiana & & $\mathrm{x}$ & & & & & & \\
\hline \multicolumn{9}{|l|}{ Gigasporaceae } \\
\hline Scutellospora fulgida & & $\mathrm{x}$ & $\mathrm{x}$ & $\mathrm{x}$ & & $\mathrm{x}$ & & \\
\hline Scutellospora sp. WAS2 & $\mathrm{x}$ & & & $\mathrm{x}$ & & $\mathrm{x}$ & & \\
\hline S. savannicola & & & & & & $\mathrm{x}$ & & \\
\hline S. heterogama & & & & & & $\mathrm{x}$ & & \\
\hline Scutellospora sp. WAS1 & $\mathrm{x}$ & & $\mathrm{x}$ & & & & & \\
\hline S. verrucosa & $\mathrm{x}$ & & $\mathrm{x}$ & & & & & \\
\hline S. pellucida & $\mathrm{x}$ & & & & & & & \\
\hline Gigaspora decipiens & & & $\mathrm{x}$ & & & $\mathrm{x}$ & & \\
\hline \multicolumn{9}{|l|}{ Ambisporaceae } \\
\hline Ambispora gerdemannii & & & $\mathrm{x}$ & & & & & \\
\hline Number of AMF species & 15 & 20 & 19 & 11 & 7 & 11 & 5 & 6 \\
\hline Total number of AMF species & 39 & & & & & & & \\
\hline
\end{tabular}

${ }^{\mathrm{a}}$ Resembling Glomus microcarpum

${ }^{\mathrm{b}}$ Resembling Glomus halonatum

${ }^{\mathrm{c}}$ Resembling Acaulospora scrobiculata 
Table 8 AM fungal species detected under various land use systems in the southern Guinea savanna of Benin

\begin{tabular}{|c|c|c|c|c|c|c|c|c|}
\hline AMF species & $\begin{array}{l}\text { Natural } \\
\text { forest } 1\end{array}$ & $\begin{array}{l}\text { Natural } \\
\text { forest } 2\end{array}$ & $\begin{array}{l}\text { Natural } \\
\text { forest } 3\end{array}$ & Yam & $\begin{array}{l}\text { Mixed } \\
\text { cropping }\end{array}$ & Peanuts & Cotton & Fallow \\
\hline \multicolumn{9}{|l|}{ Glomeraceae } \\
\hline G. etunicatum & $\mathrm{x}$ & $\mathrm{x}$ & $\mathrm{x}$ & $\mathrm{x}$ & $\mathrm{x}$ & $\mathrm{x}$ & $\mathrm{x}$ & $\mathrm{x}$ \\
\hline G. macrocarpum & $\mathrm{x}$ & $\mathrm{x}$ & $\mathrm{x}$ & $\mathrm{x}$ & $\mathrm{x}$ & $\mathrm{x}$ & $\mathrm{x}$ & $\mathrm{x}$ \\
\hline G. brohulti & $\mathrm{x}$ & $\mathrm{x}$ & & $\mathrm{x}$ & & & & $\mathrm{x}$ \\
\hline G. intraradices & $\mathrm{x}$ & $\mathrm{x}$ & $\mathrm{x}$ & $\mathrm{x}$ & $\mathrm{x}$ & & & \\
\hline G. fasciculatum & $\mathrm{x}$ & & & $\mathrm{x}$ & & & & $\mathrm{x}$ \\
\hline G. constrictum & $\mathrm{x}$ & $\mathrm{x}$ & $\mathrm{x}$ & $\mathrm{x}$ & & & $\mathrm{x}$ & \\
\hline G. claroideum & & & & & & & & $\mathrm{x}$ \\
\hline G. geosporum & & & & & & $\mathrm{x}$ & & \\
\hline G. aureum & & $\mathrm{x}$ & $\mathrm{x}$ & & $\mathrm{x}$ & & $\mathrm{x}$ & \\
\hline Glomus sp. WAG7 ${ }^{\mathrm{a}}$ & & & & & $\mathrm{x}$ & & & $\mathrm{x}$ \\
\hline G. ambisporum & $\mathrm{x}$ & & & & & & & \\
\hline G. sinuosum & & $\mathrm{x}$ & $\mathrm{x}$ & $\mathrm{x}$ & & & & \\
\hline G. taiwanense & & & $\mathrm{x}$ & $\mathrm{x}$ & & & & \\
\hline G. clavisporum & & & $\mathrm{x}$ & $\mathrm{x}$ & & & & \\
\hline G. mosseae & & & & $\mathrm{x}$ & & & & \\
\hline G. clarum & $\mathrm{x}$ & & & & & & & \\
\hline G. pachycaulis & & $\mathrm{x}$ & & & & & & \\
\hline Glomus sp. WAG2 ${ }^{\mathrm{b}}$ & & $\mathrm{x}$ & & & & & & \\
\hline Glomus sp WAG6 ${ }^{\mathrm{c}}$ & $\mathrm{x}$ & & & & & & & \\
\hline \multicolumn{9}{|l|}{ Acaulosporaceae } \\
\hline Acaulospora scrobiculata & $\mathrm{x}$ & & $\mathrm{x}$ & $\mathrm{x}$ & $\mathrm{x}$ & $\mathrm{x}$ & $\mathrm{x}$ & $\mathrm{x}$ \\
\hline A. excavata & & & $\mathrm{x}$ & $\mathrm{x}$ & $\mathrm{x}$ & & & \\
\hline A. spinosa & $\mathrm{x}$ & & $\mathrm{x}$ & & & & & \\
\hline A. mellea & $\mathrm{x}$ & & & & $\mathrm{x}$ & & & \\
\hline A. elegans & & & & $\mathrm{x}$ & & & & $\mathrm{x}$ \\
\hline Acaulospora sp. WAA2 ${ }^{\mathrm{e}}$ & & & & & & $\mathrm{x}$ & & \\
\hline A. laevis & & & & & & & & $\mathrm{x}$ \\
\hline Acaulospora sp. WAA1 ${ }^{\mathrm{d}}$ & & $\mathrm{x}$ & & & & & & \\
\hline Kuklospora colombiana & & $\mathrm{x}$ & & & & & & \\
\hline \multicolumn{9}{|l|}{ Gigasporaceae } \\
\hline S. heterogama & & & & $\mathrm{x}$ & & & & $\mathrm{x}$ \\
\hline Scutellospora sp. WAS1 & $\mathrm{x}$ & $\mathrm{x}$ & $\mathrm{x}$ & & & & & \\
\hline Scutellospora sp. WAS2 & $\mathrm{x}$ & $\mathrm{x}$ & & & & & & \\
\hline S. fulgida & & $\mathrm{x}$ & $\mathrm{x}$ & & & & & \\
\hline S. verrucosa & $\mathrm{x}$ & & & & & & & \\
\hline \multicolumn{9}{|l|}{ Entrophosporaceae } \\
\hline E. infrequens & & & $\mathrm{x}$ & & & & & \\
\hline \multicolumn{9}{|l|}{ Ambisporaceae } \\
\hline Ambispora gerdemannii & & & $\mathrm{x}$ & & & $\mathrm{x}$ & & \\
\hline \multirow[t]{2}{*}{ Total number of AMF species } & 15 & 14 & 15 & 14 & 8 & 6 & 5 & 10 \\
\hline & 35 & & & & & & & \\
\hline
\end{tabular}

${ }^{a}$ Resembling Glomus microcarpum

${ }^{\mathrm{b}}$ Resembling Glomus halonatum

${ }^{\mathrm{c}}$ Resembling Glomus arborense

${ }^{\mathrm{d}}$ Resembling Acaulospora scrobiculata

${ }^{\mathrm{e}}$ Resembling Acaulospora paulinae

Relationship between chemical soil parameters and spore density and species richness

Spore density, as well as species richness, were mostly positively correlated with soil organic carbon contents and soil $\mathrm{pH}(P<0.05)$. No significant correlation was observed, however, between available soil $\mathrm{P}$ and spore density or species richness (Table 9).
AMF in trap cultures

For unknown reasons, spore formation and mycorrhizal root colonization was low or even zero in most pots. After 10 months of trap culturing, AMF propagation was low with only four AMF species having sporulated, and most pots remaining without mycorrhiza or spore formation, even after 24 months. Only spores of Glomus etunicatum, 
Table 9 Correlation coefficients between soil chemical parameters and AM fungal spore density and species richness from 24 sites sampled in four simultaneous replicates

\begin{tabular}{lcc}
\hline Correlation factors & Correlation coefficient $(r)$ & $P$ value \\
\hline P acetic acid $\times$ AMF spore density & 0.13 & 0.18 \\
P acetic acid $\times$ AMF species richness & 0.17 & 0.09 \\
P citric acid $\times$ AMF spore density & 0.12 & 0.24 \\
P citric acid $\times$ AMF species richness & 0.19 & 0.05 \\
Carbon (humus) $\times$ AMF spore density & 0.37 & 0.0002 \\
Carbon (humus) $\times$ AMF species richness & 0.44 & $<0.0001$ \\
pH $\left(\mathrm{H}_{2} \mathrm{O}\right) \times$ AMF spore density & 0.54 & $<0.0001$ \\
pH $\left(\mathrm{H}_{2} \mathrm{O}\right) \times$ AMF species richness & 0.35 & 0.0005 \\
\hline
\end{tabular}

G. claroideum, G. aggregatum, a small-spored Glomus sp., and a few spores of Gigaspora gigantea were extracted during the first 10 months. After 2 years, a further two species were recovered: Paraglomus occultum and Acaulospora myriocarpa. The latter species had not been detected in the field samples.

\section{Discussion}

Our study amounts to the first comprehensive assessment of AMF species richness in the yam-growing region of West Africa, represented in this case by Benin. We detected a total of 60 AMF species (59 from field samples and $A$. myriocarpa additionally from trap cultures) belonging to eight AMF genera in soils from three separate ecological zones of Benin. This reflects results from studies in other tropical areas, such as India (Muthukumar and Udaiyan 2000), Central America (Husband et al. 2002a, b), and East Africa (Mathimaran et al. 2007), albeit with slightly higher species richness recorded in the present study. Data shown here may still represent an underestimation, however, as it is likely that not all AMF present will have sporulated at the time of sampling (see Bever et al. 1996, 2001), and especially as our trap culturing largely failed to support the field data. By using morphological tools for identification, AMF species richness may also be underestimated because some species rarely, if ever sporulate, or the spores isolated from field are degraded and not suitable for identification purposes (Douds and Millner 1999; Rodriguez et al. 2005). New data from ongoing studies further indicates that the timing of sampling in the current study, towards the end of the wet season, was not optimal, and at least partially explains why AMF propagation was largely unsuccessful (Tchabi et al., unpublished). However, the intensive sampling design used in the current study will undoubtedly represent a high-quality reflection of the occurrence and density of AMF species in the West African "yam belt".

Forty-seven AMF species were detected in the SU ( $\sim 5$ months wet season), while 39 were recovered from the $\mathrm{NG}(\sim 7$ months wet season) and 35 in the SG ( $\sim 8$ months wet season), respectively. The findings indicate that AMF species richness decreases with increasing length of wet season and towards the more humid tropics. However, 46 AMF species were detected from the SG+NG combined, similar to the number in the SU. Furthermore, species of the Gigasporaceae (mainly Scutellospora, but also Gigaspora spp.) became more numerous with increasing duration of annual dry season. Less obviously, Acaulospora and Glomus species numbers decreased with reducing duration of the annual dry season. Relatively high numbers of Scutellospora and Acaulospora spp. were also reported by Mathimaran et al. (2007) in a Kenyan savanna (with approximately 5 months annual rainfall) and also by Lekberg et al. (2007) in a Zimbabwean savanna (with approximately 5 months annual rainfall) in light textured soils. Indeed, most Scutellospora spp. have been described from warmer climates characterized by pronounced rainfall and a dry season (e.g., in Mediterranean and tropical and subtropical savannas, such as S. savannicola, $S$. cerradensis, $S$. nigra). In drier climates, with fewer rainfall months and lower total annual rainfall, Gigasporaceae tend to be represented by a small number of cosmopolitan species (Uhlmann et al. 2004; Bashan et al. 2007) if species of this family occur at all (Stutz and Morton 1996). We conclude that SU has a high AMF species richness and that a relatively long dry season $(\sim 7$ months) does not negatively affect but rather seems to stimulate species richness in this area of African savannas. It is also possible that species adapted to low water conditions, or species with a pronounced seasonal life cycle, may be more competitive in SU than in $\mathrm{NG}$ or SG (e.g., some Scutellospora and Gigaspora spp.). It would be interesting to further investigate the effect of rainfall and dry season length in the drier sub-Saharan savannas and deserts where, under the driest conditions, only a few Glomus and Diversispora spp., and rarely, an Acaulospora sp., can be expected (Friberg 2001) to gain a better understanding of the adaptation of individual species along the climatic and vegetation gradient from tropical rain forest to the Sahelian desert.

Independent of the ecological zone, AMF species richness decreased with land use intensification, irrespective of duration of soil cultivation. The high species richness of the natural forest savannas was not restored, however, by 
long-term fallows. Species of Gigasporaceae were most negatively affected after conversion from natural forest savannas into agro-ecosystems and appeared most sensitive to recovery in the fallows, while several Glomus spp. and a few Acaulospora spp. were barely affected (Table 5) or reacted positively (e.g., G. etunicatum and A. scrobiculata). This observation concurs with the findings from temperate agro-ecosystems of Jansa et al. $(2002,2003)$ and Oehl et al. (2003, 2004, 2005) who observed negative correlations between land use intensification and soil disturbance and the presence of Scutellospora spp., which is possibly related to the particularities in anastomosis processes of Scutellospora spp. (de la Providencia et al. 2005). In addition, Menéndez et al. (2001) demonstrated that tillage and cereal monoculture negatively affected AMF species richness. As found by Oehl et al. (2003, 2004, 2005) for Central European regions, also in the sub-Saharan savannas, the majority of sporocarpic Glomus spp. and Entrophospora infrequens were strongly affected by soil cultivation, becoming undetectable after the first year of arable land use, which, in the current study, would correspond with yam cultivation (Table 5). It is possible that the persistence of such species as G. etunicatum, G. macrocarpum, $G$. intraradices, and $A$. scrobiculata is related to their ability to rapidly colonize roots from spreading external hyphae (Kurle and Pfleger 1994) or to the intensity and speed of spore formation (Oehl et al. 2003).

Spore density and species richness were not correlated to available $\mathrm{P}$ but were positively correlated with soil organic carbon and soil $\mathrm{pH}$. Similar results were reported by Johnson (1991) and Mohammad et al. (2003) who found that spore production increased with soil $\mathrm{pH}$ and organic carbon. Gryndler et al. (2006) also found that organic fertilizer application leads to increased external AMF mycelium development. No relationship between available $\mathrm{P}$ and spore density and species richness can be explained by the specific situation of our study, as a dramatic decrease in spore density and species richness was observed in the intensively managed cotton fields, compared to the natural forest savannas, despite the fact that soil $\mathrm{P}$ levels were similar at the time of sampling. However, it is well known that the response of AMF to available $\mathrm{P}$ is variable (Jasper et al. 1989) and, according to Neumann and George (2004) and Subramanian et al. (2006), the application of P can influence spore production either positively or negatively. Certainly, the period of time between forest clearance and cotton cultivation (4 years; Table 2 ), when other crops were cultivated without external fertilizer input, was already associated with species richness decline. In summary, the positive association between organic carbon contents and soil $\mathrm{pH}$ with spore density and species richness may reflect the change from natural ecosystems to crop production systems, particularly with application of acidifying fertilizers in the most intensive cropping system ( $\mathrm{Na}$ Bhadalung et al. 2005). Neither parameter can be considered independently from each other for their impact on spore abundance and species richness (Coughlan et al. 2000).

As in the mono-cropped fields several weed species were often present, AMF species recovered from these sites cannot unequivocally be identified as the AMF symbionts of the cultivated crop. To address such aspects, it would be necessary to apply molecular root analyses for single plant species. In addition, AMF dynamics within a single season cannot be deduced, but need to be interpreted in respect to long-term community dynamics in tropical agroecosystems. The natural forest savannas had a high AMF species and genus richness, but which remained relatively high for only one season, under yam, after forest clearance. Thereafter, the decline was precipitous and did not recover even after 7 years of natural fallow. We assume that at least some of the natural savannas - undisturbed for at least 25 30 years before sampling - had been used for agricultural purposes previously, and thus, a relatively high AMF species richness had restored during this period. However, with the continuous erosion of fallow period length in West Africa and intensification of farming practices (IITA 2006), it is likely that AMF communities will be subject to unrecoverable losses.

High levels of infective AMF propagules (Sieverding 1991) and soil microbial activity are accepted as preconditions for sustainable low-input farming systems (Mäder et al. 2002), especially in the tropics (Oberson et al. 2004; Franchini et al. 2005). Present farming practices need to be studied with respect to the management of AMF to better understand their importance, especially at the specific level. A common recommendation has often been the use of mixed culture or alley cropping systems with legumes to introduce nitrogen to the soil/plant system. However, our results indicated that mixed cropping of peanuts and maize had no effect on the AMF spore density and species richness when compared to peanuts alone. Moreover, the decrease in AMF species richness after slash and burn and yam production was quite dramatic. Yam is usually grown in 70 - to $120-\mathrm{cm}$-high mounds heaped up following the high level of soil disturbance caused by the slash and burn of the forest, with further disturbance taking place at harvest. Such practices would certainly negatively affect both the AMF hyphal networks and the soil microbial biomass. With the change in cropping styles towards intensification, coupled with loss, or reduction of fallow periods as land becomes scarcer, there is need to assess the potentials of $\mathrm{AMF}$ and measures for maintaining $\mathrm{AMF}$ levels and communities for soil fertility and sustainable crop production. Therefore, besides yam being a highly important staple food crop in the study area, it is also particularly interesting in respect to AMF, as ongoing 
studies indicate it to be highly AM-dependent (personal observations). However, current soil and crop management strategies for yam would appear to have a strong negative impact on AMF communities, which will ultimately affect the AMF effectivity for the entire crop rotation. To improve the sustainability of yam production systems, it is suggested that future studies focus on the importance of AMF, and beneficial soil microorganisms in general, to yam production itself in addition to other crops in the traditional rotational system.

Acknowledgments This study has been supported by a $\mathrm{PhD}$ research program of the Swiss Center for International Agriculture (ZIL: http://www.rfpp.ethz.ch).

\section{References}

Adjakidje V (1984) Contribution à l'étude botanique des savanes guinéennes de la République Populaire du Bénin-Thèse du troisième cycle. Université de Bordeaux III, Bordeaux

Adjanohoun EJ (1989) Contribution aux études ethnobotaniques et floristiques en Republique Populaire du Bénin. Agence de Cooperation Culturelle et Technique, Paris

Bashan Y, Khaosaad T, Salazar BG, Ocampo JA, Wiemken A, Oehl F, Vierheilig H (2007) Mycorrhizal characterization of the boojum tree, Fouquieria columnaris, an endemic ancient tree from the Baja California Peninsula, Mexico. Trees 21:329-335

Bever JD, Morton JB, Antonovics J, Schultz PA (1996) Hostdependent sporulation and species diversity of arbuscular mycorrhizal fungi in a mown grassland. J Ecol 84:71-82

Bever JD, Schultz PA, Pringle A, Morton JB (2001) Arbuscular mycorrhizal fungi: more diverse than meets the eye, and the ecological tale of why. Bioscience 51:923-931

Brundrett M, Melville L, Peterson L (1994) Practical methods in mycorrhizal research. Mycologue Publications, University of Guelph, Guelph, Ontario, Canada

Cardoso I, Kuyper TW (2006) Mycorrhizas and tropical soil fertility. Agric Ecosyst Environ 116:72-84

Castillo CG, Borie F, Godoy R, Rubio R, Sieverding E (2006) Diversity of mycorrhizal plant species and arbuscular mycorrhizal fungi in evergreen forest, deciduous forest and grassland ecosystems of Southern Chile. J Appl Bot Food Qual 80:40-47

Coughlan AP, Dalpè Y, Lapointe L, Pichè Y (2000) Soil pH-induced changes in root colonization, diversity and reproduction of symbiotic arbuscular mycorrhizal fungi from healthy and declining maple forests. Can J For Res 30:1543-1554

Dalpé Y, Diop TA, Plenchette C, Gueye M (2000) Glomales species associated with surface and deep rhizosphere of Faidherbia albida in Senegal. Mycorrhiza 10:125-129

De la Providencia IE, de Souza FA, Fernandez F, Delmas NS, Declerck S (2005) Arbuscular mycorrhizal fungi reveal distinct patterns of anastomosis formation and hyphal healing mechanisms between different phylogenic groups. New Phytol 165:261-271

Defoer T, Scoones I (2001) Participatory approaches to integrated soil fertility management. In: Scoones I (ed) Dynamics and diversity: soil fertility management and farming livelihoods in Africa: case studies from Ethiopia, Mali and Zimbabwe. Earthscan Publications Ltd, London, UK, pp 64-67

Douds D, Millner P (1999) Biodiversity of arbuscular mycorrhizal fungi in agroecosystems. Agric Ecosyst Environ 74:77-93
Duponnois R, Plenchette C, Thioulouse J, Cadet P (2001) The mycorrhizal infectivity and arbuscular mycorrhizal fungal spore communities in soils of different aged fallows in Senegal. Appl Soil Ecol 17:239-251

Egerton-Warburton L, Allen EB (2000) Shifts in arbuscular mycorrhizal communities along an anthropogenic nitrogen deposition gradient. Ecol Appl 10:484-496

Eom AH, Hartnett DC, Wilson GWT (2004) Host plant species effects on arbuscular mycorrhizal fungal communities in tallgrass prairie. Ecology 122:435-444

Franchini JC, Crispino C, Souza RA, Torres E, Hungria M (2005) Microbiological parameters as indicators of soil quality under various soil management and crop rotation systems in southern Brazil. Soil Till Res 92:18-29

Friberg S (2001) Distribution and diversity of arbuscular mycorrhizal fungi in traditional agriculture on the Niger inland delta, Mali, West Africa. CBM: Skriftserie 3:53-80

Gai JP, Cai XB, Feng G, Christie P, Li XL (2006) Arbuscular mycorrhizal fungi associated with sedges on the Tibetan plateau. Mycorrhiza 16:151-157

Gerdemann JW, Trappe JM (1974) Endogonaceae in the Pacific Northwest. Mycologia Memoir 5:1-76

Gryndler M, Larsen J, Hrselova H, Rezacova V, Gryndlerova H, Kubat J (2006) Organic and mineral fertilization, respectively, increase and decrease the development of external mycelium of arbuscular mycorrhizal fungi in a long-term field experiment. Mycorrhiza 16:159-166

Husband RE, Allen HJ, Peter W, Young JPW (2002a) Temporal variation in the arbuscular mycorrhizal communities colonising seedlings in a tropical forest. FEMS Microbiol Ecol 42:131136

Husband R, Herre EA, Turner SL, Gallery R, Young JPW (2002b) Molecular diversity of arbuscular mycorrhizal fungi and patterns of host association over time and space in a tropical forest. Mol Ecol 11:2669-2678

IITA 2004 International Institute of Tropical Agriculture. Annual report. pp. 196

IITA 2006 International Institute of Tropical Agriculture. Annual report. pp. 201

Ingleby K, Walker C, Mason PA (1994) Acaulospora excavata sp. nov.- an endomycorrhizal fungus from Cote d'Ivoire. Mycotaxon 50:99-105

Jansa J, Mozafar A, Anken T, Ruh R, Sanders I, Fossard E (2002) Diversity and structure of AMF communities as affected by tillage in a temperate soil. Mycorrhiza 12:225-234

Jansa J, Mozafar A, Kuhn G, Anken T, Ruh R, Sanders IR, Frossard E (2003) Soil tillage affects the community structure of mycorrhizal fungi in maize roots. Ecol Appl 13:1164-1176

Jasper DA, Abbott LK, Robson AD (1989) Soil disturbance reduced the infectivity of external hyphae of vesicular-arbuscular mycorrhizal fungi. New Phytol 112:93-99

Johnson NC (1991) Dynamics of vesicular-arbuscular mycorrhizae during old field succession. Oecologia 86:349-358

Johnson NC, Copeland PJ, Crookston RK, Pfleger FL (1992) Mycorrhizae - possible explanation for yield decline with continuous corn and soybean. Agron J 84:387-390

Koske RE, Gemma JN, Jackson N (1997) Arbuscular mycorrhizal fungi associated with three species of turfgrass. Can J Bot 75:320-332

Kurle JE, Pfleger FL (1994) Arbuscular mycorrhizal fungi spore population respond to conversions between low-input and conventional management practices in corn-soybean rotation. Agron J 86:467-475

Landis FC, Givnish TJ, Gargas A (2004) The relationship between plant understory and arbuscular mycorrhizal fungal communities in American midwestern oak savannas. New Phytol 164:493-504 
Lekberg Y, Koide RT, Rohr JR, Aldrich-Wolfe L, Morton JB (2007) Role of niche restrictions and dispersal in the composition of arbuscular mycorrhizal fungal communities. J Ecol 95:95-105

Lovelock CE, Ewel JJ (2005) Links between tree species, symbiotic fungal diversity and ecosystem functioning in simplified tropical ecosystems. New Phytol 167:219-228

Lovera M, Cuenca G (2007) Diversity of arbuscular mycorrhizal fungi (AMF) and mycorrhizal potential of the soil from a natural and a disturbed savannah from La Gran Sabana, Venezuela. Interciencia $32: 108-114$

Lovelock CE, Andersen K, Morton JB (2003) Arbuscular mycorrhizal communities in tropical forests are affected by host tree species and environment. Oecologia 135:268-279

Mäder P, Fließbach A, Dubois D, Gunst L, Fried P, Niggli U (2002) Soil fertility and biodiversity in organic farming. Science 296:1694-1697

Maia LC, Trufem SFB (1990) Vesicular-arbuscular mycorrhizal fungi in cultivated soils in Pernambuco State, Brazil. Revista Brasil Bot 13:89-95

Mathimaran N, Ruh R, Jama B, Verchot L, Frossard E, Jansa J (2007) Impact of agricultural management on arbuscular mycorrhizal fungal communities in Kenyan Ferralsol. Agric Ecosyst Environ 119:22-32

Menéndez AB, Scervino JM, Godeas AM (2001) Arbuscular mycorrhizal populations associated with natural and cultivated vegetation on a site of Buenos Aires province, Argentina. Biol Fertil Soils 33:373-381

Mohammad MJ, Hamad SR, Malkawi HI (2003) Population of arbuscular mycorrhizal fungi in semi-arid environment of Jordan as influenced by biotic an abiotic factors. J Arid Environ 53:409417

Morton JB, Benny GL (1990) Revised classification of arbuscular mycorrhizal fungi (Zygomycetes): a new order, Glomales, two new suborders, Glomineae and Gigasporineae, and two families, Acaulosporaceae and Gigasporaceae, with an emendation of Glomaceae. Mycotaxon 37:471-491

Muthukumar T, Udaiyan K (2000) Arbuscular mycorrhizas of plants growing in the Western Ghats region, Southern India. Mycorrhiza 9:297-313

Na Bhadalung N, Suwanarit A, Dell B, Nopamornbodi O, Thamchaipenet A, Rungchuang J (2005) Effects of long-term NP-fertilization on abundance and diversity of arbuscular mycorrhizal fungi under a maize cropping system. Plant Soil 270:371-382

Neumann E, George E (2004) Colonisation with the arbuscular mycorrhizal fungus Glomus mosseae (Nicol. \& Gerd.) enhanced phosphorus uptake from dry soil in Sorghum bicolor (L.). Plant Soil 261:245-255

Nicolson TH, Schenck NC (1979) Endogonaceous mycorrhizal endophytes in Florida. Mycologia 71:178-198

Oberson A, Friesen DK, Rao IM, Bühler S, Frossard E (2004) Phosphorus transformations in an oxisol under contrasting landuse systems: the role of the soil microbial biomass. Plant Soil 237:197-210

Oehl F, Sieverding E, Ineichen K, Mäder P, Boller T, Wiemken A (2003) Impact of land use intensity on the species diversity of arbuscular mycorrhizal fungi in agroecosystems of Central Europe. Appl Environ Microbiol 69:2816-2824

Oehl F, Sieverding E, Mäder P, Dubois D, Ineichen K, Boller T, Wiemken A (2004) Impact of long-term conventional and organic farming on the diversity of arbuscular mycorrhizal fungi. Oecologia 138:574-583

Oehl F, Sieverding E, Ineichen K, Ris E-A, Boller T, Wiemken A (2005) Community structure of arbuscular mycorrhizal fungi at different soil depths in extensively and intensively managed agroecosystems. New Phytol 165:273-283

Old KM, Nicolson TH, Redhead JF (1973) A new species of mycorrhizal Endogone from Nigeria with a distinctive spore wall. New Phytol 72:817-823

Picone C (2000) Diversity and abundance of arbuscular-mycorrhizal spores in tropical forest and pasture. Biotropica 32:734-750

Redecker D (2000) Specific PCR primers to identify arbuscular mycorrhizal fungi within colonized roots. Mycorrhiza 10:73-80

Rodriguez A, Clapp JP, Robinson L, Dodd JC (2005) Studies on the diversity of the distinct phylogenetic lineage encompassing Glomus claroideum and Glomus etunicatum. Mycorrhiza 15:33-46

Sanginga N, Carsky RJ, Darshiell K (1999) Arbuscular mycorrhizal fungi respond to rhizobial inoculation and cropping systems in farmers' fields in the Guinea savanna. Biol Fertil Soils 30:179-186

Schenck NC, Pérez Y (1990) Manual for the identification of VA mycorrhizal fungi. Synergistic-Publications, Gainesville, Florida

Schenck NC, Spain JL, Sieverding E, Howeler RH (1984) Several new and unreported vesicular-arbuscular mycorrhizal fungi (Endogonaceae) from Colombia. Mycologia 76:685-699

Sieverding E (1988) Two new species of vesicular arbuscular mycorrhizal fungi in the Endogonaceae from tropical high lands of Africa. Angew Bot 62:373-380

Sieverding E (1989) Ecology of VAM fungi in tropical agrosystems. Agric Ecosyst Environ 28:369-390

Sieverding E (1991) Vesicular-arbuscular mycorrhiza management in tropical agrosystems. Technical Cooperation, Germany

Smith SE, Read DJ (1997) Mycorrhizal symbiosis, 2nd edn. Academic, San Diego

Stutz J, Morton JB (1996) Successive pot cultures reveal high species richness of indigenous arbuscular endomycorrhizal fungi in arid ecosystems. Can J Bot 74:1883-1889

Subramanian KS, Santhanakrishnan P, Balasubramanian P (2006) Responses of field grown tomato plants to arbuscular mycorrhizal fungal colonization under varying intensities of drought stress. Scientia Horticulturae 107:245-253

Uhlmann E, Gorke C, Petersen A, Oberwinkler F (2004) Arbuscular mycorrhizae from semiarid regions of Namibia. Can J Bot 82:645-653

Uhlmann E, Gorke C, Petersen A, Oberwinkler F (2006) Arbuscular mycorrhizae from arid parts of Namibia. J Arid Environ 64:221-237

Wu B, Hogetsu T, Isobe K, Ishii R (2007) Community structure of arbuscular mycorrhizal fungi in a primary successional volcanic desert on the southeast slope of Mount Fuji. Mycorrhiza 17:495-506

Wubet T, Weiß M, Kottke I, Oberwinkler F (2003) Morphology and molecular diversity of arbuscular mycorrhizal fungi in wild and cultivated yew (Taxus baccata). Can J Bot 81:255-266

Wubet T, Weiß M, Kottke I, Teketay D, Oberwinkler F (2004) Molecular diversity of arbuscular mycorrhizal fungi in Prunus africana, an endangered medicinal tree species in dry Afromontane forests of Ethiopia. New Phytol 161:517-528

Wubet T, Weiß M, Kottke I, Teketay D, Oberwinkler F (2006) Phylogenetic analysis of nuclear small subunit rDNA sequences suggests that the endangered African pencil cedar, Juniperus procera, is associated with distinct members of Glomeraceae. Mycol Res 110:1059-1069 